\title{
Sikap dan Norma Subjektif Terhadap Intensi Mengkonsumsi Produk
}

\author{
Adi Koncara $^{1 *}$ dan Radhi Abdul Halim Rachmat ${ }^{2}$ \\ ${ }^{1}$ Fakultas Bisnis dan Manajemen, Universitas Widyatama, Indonesia \\ ${ }^{2}$ Fakultas Ekonomi, Universitas Widyatama, Indonesia
}

\begin{abstract}
:
Characteristics that affect consumption behavior adolescents are often influenced by psychological factors. This study explores intention based theory of Ajzen and Fishbein be a model of human behavior known as Theory of Reasoned Action (TRA). The object of the research is a high school student in Bandung. From the 100 questionnaires, research results show that the intention to consume a product is partial effect on the student's attitude (such as strong, stylish, handsome, sociable, flexible, bold). While the intention is not partial effect on the subjective norms (such as friend, idol, family). Attitudes and subjective norms simultaneously does not effect to the intention to consume a product.
\end{abstract}

Keywords: theory of reasoned action, attitude, subjective norm, intention, method successive interval

\section{PENDAHULUAN}

Menurut pemberitaan Kompas (Utamadi, 2002), didalam tajuk yang berjudul "Rokok Bagi Remaja, Gaya atau Bahaya?", hasil studi menunjukkan bahwa perokok berat telah memulai kebiasan merokak sejak usia belasan tahun, dan hampir tidak ada perokok berat yang memulai pada saat dewasa. Karena itulah masa remaja seraing kali dianggap masa kritus yang menentukan apakah nantinya siswa SMU menjadi perokok atau bukan. Kebanyakan remaja memulai kebiasaan merokok karena ikut-ikutan teman, selain karena terpengaruh image yang diciptakan oleh preodusen rokok (misalnya, dengan menggunakan idola remaja sebagai bintang iklan) atau karena punya orang tua perokok.

Karateristik yang mempengaruhi tingkah laku konsumsi remaja yang di pengaruhi faktor psikologi yaitu ,motivasi, persepsi, pengetahuan, serta keyakinan

*Email korespondensi:

Adi Koncara

adi.koncara@widyatama.ac.id dalam sikap (Kotler, 1997) hasil penelitian mengenai Analisis profil Demografis dan Psikografis perokok (Amana, 2002) menunjukan bahwa karateristik dari profil psikografis yang diwakili oleh studi self concept khususnya dimensi ideal social self concept berupa, merokok menunjukkan kebutuhan untuk terlihat oleh orang lain sebagai orang yang kuat, gaya, gaul, fleksibel, berani.

\section{Paradigma Penelitian}

Dari fenomena tersebut, peneliti tertarik untuk mengkaji mengenai konsumsi produk $\mathrm{X}$ (rokok) dikalangan remaja khususnya remaja SMU, yang berhubungan dengan teori Reasoned Action yang ditemukan Fisbein dan Ajzen. Menurut teori Reasoned Action dari (Fishbein dan Ajzen, 1980) perilaku selalu didahului oleh intensi, dan intensi muncul disebabkan oleh sikap dan norma subyektif. Oleh karena itu berdasarkan pada teori tersebut maka penelitian merasa tertarik untuk menerapkannya dalam penelitian ini dan sekaligus mengkaji secara empiris 
keterkaitan antara sikap, norma subyektif, intensi dan mengkonsumsi rokok dikalangan remaja, khususnya pada siswa SMU di Bandung.

\section{Identifikasi Masalah}

Berdasaran latar belakang penelitian, maka penulis mendapati pokok permasalahan, antara lain:

1. Bagaimana pengaruh sikap mengkonsumsi rokok terhadap intensi untuk rokok.

2. Bagaimana pengaruh norma subjektif mengkonsumsi rokok terhadap intensi untuk rokok.

Manfaat praktis penelitian ini untuk mendapatkan informasi permasalahan tentang perilaku mengkonsumsi rokok di kalangan remaja di sebuah SMU di kota Bandung yang berhubungan dengan intensi yang dipengaruhi oleh sikap dan norma subjektif. yang menampilkan sikap-sikap seperti kuat, gaya, gagah, gaul, fleksibel dan berani yang berpengaruh terhadap intensi mengkonsumsi rokok di kalangan remaja SMU.

\section{TINJAUAN PUSTAKA \\ Kerangka Teoritis}

Sikap adalah kecenderungan yang dipelajari dipelajari untuk bertindak atau merespons secara konsisten dan mengevaluasi secara positif atau negatif terhadap obyek atau kategori tertentu (Fisbein, 1975). Sementara itu norma Subjektif (Fisbein dan Ajzen, 1975: 302) adalah persepsi individu bahwa kebanyakan dari orang-orang yang penting (significat person) bagi dirinya mengharapkan individu untuk menampilkan atau tidak. Intensi sendiri (Fisbein dan Ajzen, 1975) terdiri dari 4 elemen yaitu : tingkah laku, objek target yang mengarah tingkah laku, situasi dimana tingkah laku ditampilkan dan waktu saat ditampilkan tingkah laku.

Theory Reasoned Action (Ajzen \& Fishbein, 1980) menyediakan model yang memiliki potensi manfaat untuk memprediksi niat untuk melakukan perilaku yang didasarkan pada sikap individu dan keyakinan normatif. Model ini dikembangkan untuk mengakomodasi variabel dan model yang dihasilkan teori bernama Planed Behaviour Theory (Ajzen, 1991).

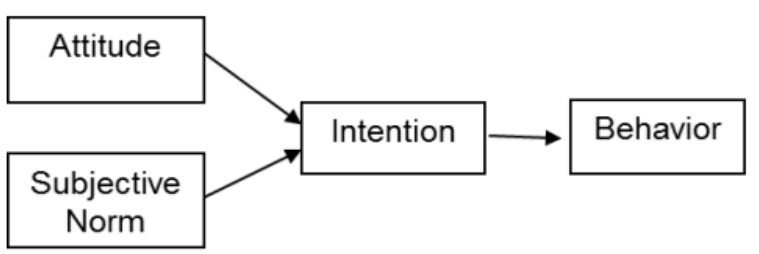

Gambar 1 Theory of Reasoned Action (Fishbein dan Ajzen, 1980)

\section{METODOLOGI PENELITIAN}

Metodologi penelitan yang digunakan adalah metode penelitian survei, merupakan studi yang bersifat kuantitaitf yang digunakan untuk meneliti gejala suatu kelompok atatu perilaku individu. Pada umumnya survei menggunakan kuesioner sebagai alat pengambil data.

\section{Kerangka Pemikiran}

Berdasarkan kerangka pemikiran pada gambar 2 maka penulis mencoba merumuskan dua hipotesis yang merupakan kesimpulan sementara dari penelitian berikut:

Hipotesis 1: ada pengaruh yang signifikan antara sikap terhadap intensi mengkonsumsi rokok.

Hipotesis 2: ada pengaruh yang signifikan antara norma subjektif terhadap terhadap intensi mengkonsumsi rokok.

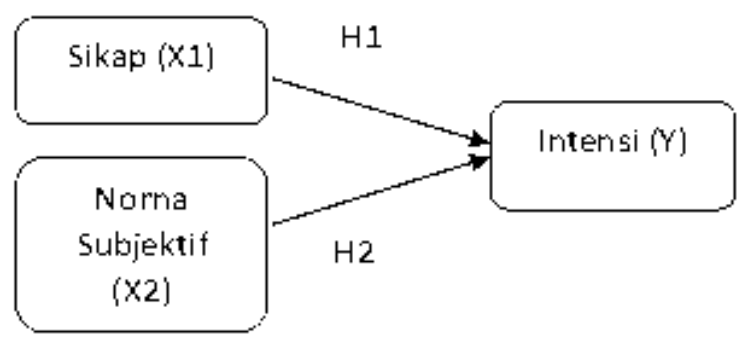

Gambar 2 Kerangka Pemikiran 
Tabel 1 Operasionalisasi Variabel

\begin{tabular}{|l|l|l|l|c|}
\hline \multicolumn{1}{|c|}{ Variabel } & Sub Variabel & \multicolumn{1}{|c|}{ Konsep Variabel } & \multicolumn{1}{|c|}{ Indikator } & Skala \\
\hline $\begin{array}{l}\text { Bebas } \\
\text { (X1) }\end{array}$ & Sikap (X1) & $\begin{array}{l}\text { Seseorang berkeyakinan bahwa } \\
\text { mengkonsums rokok akan } \\
\text { mencerminkan: gagah, gaya, gaul, } \\
\text { fleksibel, berani dan kuat }\end{array}$ & $\begin{array}{l}\text { Tingkat keyakinan } \\
\text { seseorang terhadap } \\
\text { sikap }\end{array}$ & Ordinal \\
\hline $\begin{array}{l}\text { Bebas } \\
(\mathrm{X} 2)\end{array}$ & $\begin{array}{l}\text { Norma } \\
\text { Subjektif (X2) }\end{array}$ & $\begin{array}{l}\text { Peresepsi seseorang terhadap } \\
\text { opini/ pengaruh/ anjuran dari } \\
\text { significat person seperti : teman, } \\
\text { idola, dan keluarga }\end{array}$ & $\begin{array}{l}\text { Tingkat keyakinan } \\
\text { seseorang terhadap } \\
\text { opini }\end{array}$ & Ordinal \\
\hline $\begin{array}{l}\text { Tidak Bebas } \\
(\mathrm{Y})\end{array}$ & Intensi (Y) & $\begin{array}{l}\text { Keinginan yang didasari pengaruh } \\
\text { sikap dan norma subjektif }\end{array}$ & $\begin{array}{l}\text { Tingkat keinginan } \\
\text { seseorang }\end{array}$ & Ordinal \\
\hline
\end{tabular}

\section{Populasi dan Sampel Penelitian}

Populasi penelitan adalah sebuah SMU di bandung dengan cara random sampling, teknik penarikan sampel dengan menggunakan power analysis (Cohen \& Cohen, 1983: 116-118) didapat minimal 83 atau lebih sampel minimal. Survey berupa kuesioner dipersiapkan dan dilakukan ujicoba terhadap 30 siswa di sebuah sekolah di Bandung.

$$
\text { Survey dilakukan berdasarkan }
$$
modifikasi dari penelitian sebelumnya (Nurhayati, 2001) yang mana pembobotan skor kuesioner untuk sangat setuju diberikan bobot nilai 5 dan jawaban sangat tidak setuju diberikan bobot nilai 1. 100 Kuesioner yang telah di uji validitas dan reliabilitas konstruk dan kontennya disebarkan untuk mendapatkan data primer.

\section{Operasionalisasi Variabel} ini antara lain:

Variabel yang diteliti pada penelitian

1. Variabel Dependen: Intensi (Y),

2. Variabel Independen: Sikap (X1), dan

3. Variabel Independen: Norma Subjektif (X2).

\section{Transformasi Data Melalui Method of Succesive Interval}

Data mentah dari kuesioner yang berskala ordinal terlebih dahulu di transformasikan tingkat pengukurannya ke tingkat interval dengan menggunakan teknik Method of Sucessive Interval (Hys, 1969:39). Adapun tahapan metode tersebut adalah :

1. Untuk setiap pertanyaan hitung frekuensi jawaban setiap kategori (pilihan jawaban)

2. Berdasarakan frekuensi setiap kategorinya hitung proporsinya.

3. Dari proporsi yang diperoleh hitung proporsi kumulatif untuk setiap kategori.

4. Tentukan pula nilai batas $\mathrm{Z}$ untuk setiap kategori.

5. Hitung scale value (nilai interval ratarata) untuk setiap kategori melalui persamaan berikut :

Scale value $=($ density at lower limit density at upper limit) / (area under limit - area under lower limit)

6. Hitung score (nilai hasil transformasi) untuk setiap kategori melalui persamaan berikut :

$$
\begin{aligned}
& \text { Score }=\text { Scale Value }+\mid \text { Scale Value } \\
& \text { minimum } \mid+1
\end{aligned}
$$

Proses ini dilakukan untuk setiap pertanyaan, sehingga, penulis mempunyai 20 hasil tranformasi data dari skala ordinal ke interval dengan perhitungan MSI.

\section{Pengolahan Data Statistik}

Teknik regresi berganda (Dajan, 1986) ini digunakan untuk mengetahui hubungan fungsional antara variabel dependen dengan dua atau lebih variabel 
Tabel 2 Koefisien Regresi

\begin{tabular}{|c|c|c|c|c|c|}
\hline \multirow{2}{*}{ Model } & \multicolumn{2}{|c|}{$\begin{array}{c}\text { Unstandardized } \\
\text { Coefficient }\end{array}$} & $\begin{array}{c}\text { Standardized } \\
\text { Coefficient }\end{array}$ & \multirow{2}{*}{ T } & \multirow{2}{*}{ Sig. } \\
\cline { 2 - 5 } & B & Std. Error & Beta & & \\
\hline Constant & 3,125 & 0,257 & & 12,143 & 0 \\
\hline Sikap & 9,910 & 0,006 & 0,228 & 6,480 & 0,112 \\
\hline $\begin{array}{c}\text { Norma } \\
\text { Subjektif }\end{array}$ & $-7,180$ & 0,015 & $-0,0070$ & -.048 & 0,962 \\
\hline
\end{tabular}

Tabel 3 Model Regresi

\begin{tabular}{|l|c|c|c|c|}
\hline Model & $\mathbf{R}$ & $\mathbf{R}^{\mathbf{2}}$ & Adjusted $\mathbf{R}^{\mathbf{2}}$ & Std. Error of the Estimate \\
\hline Intensi & 0,223 & 0,05 & 0,030 & 0,810 \\
\hline
\end{tabular}

independen. Rumus dari regresi berganda linear adalah:

$$
\hat{Y}=a_{0}+b_{1} X_{1}+b_{2} x X_{2}+e
$$

Rumus diatas dapat dicari dengan menggunakan 3 persamaan dibawah ini:

$$
\begin{array}{ll}
\Sigma \mathrm{Y} & =n a_{0}+b_{1} \Sigma X_{1}+b_{2} \Sigma X_{2} \\
\Sigma \mathrm{X}_{1} \mathrm{Y} & =a_{0}+\Sigma X_{1}+b_{1} \Sigma X_{1}^{2}+b_{2} \Sigma X_{1} X_{2} \\
\Sigma \mathrm{X}_{2} \mathrm{Y} & =a_{0} \Sigma X_{2}+b \Sigma X_{1} X_{2}+b_{2} \Sigma X_{2}^{2} \\
& \text { Jika defiasi antara } \mathrm{X}_{\mathrm{I}} \text { dan } \bar{x}_{I}
\end{array}
$$

dinyatakan sebagai $\mathrm{x}_{\mathrm{i}}=\mathrm{x} 1-\bar{x}_{i}$ maka ketiga persamaan linear diatas dapat disederhanakan menjadi:

$0=0$

$\Sigma \mathrm{y}_{1}=b_{1} \Sigma x_{1}^{2}+b_{2} \Sigma x_{1} x_{2}$

$\Sigma \mathrm{y}_{2}=b_{1} \Sigma x_{1} x_{2}+b_{2} \Sigma x_{2}^{2}$

Dimana,

$\Sigma x_{1}^{2}=\Sigma X_{i}^{2}-n \bar{X}_{i}^{2}$

$\Sigma x_{i} x_{j}=\Sigma X_{i}-X_{j}-n \bar{X}_{i} \bar{X}_{j}$

Besaran koefesien a diberikan sebagai:

$a=\bar{Y}-b_{1} \bar{X}_{1}-b_{2} \bar{X}_{2}$

Pada hakekatnya $b_{1}=$ koefesien regresi berganda (coeffecient of multiple regression) yang mengukur besaran perubahan variabel dependen $\mathrm{Y}$, sehubungan dengan perubahan variabel independen $\mathrm{X}_{1}$ (sikap) dengan asumsi variabel independen $\mathrm{X}_{2}$ (norma subjektif) konstan, koefesien regresi berganda $b_{2}$ mengukur besaran perubahan variabel $\mathrm{Y}$ sehubungan dengan perubahan variabel independen $X_{2}$, dengan asumsi variabel independen $\mathrm{X}_{1}$ konstan.

\section{HASIL PENELITIAN DAN DISKUSI Hasil Penelitian}

Populasi penelitan adalah sebuah SMU di Bandung, sampel diambil dengan cara random samping, dengan dengan $\alpha=$ 0,05, didapatkan sampel minimanl 83 . Kuesioner yang telah dilakukan uji coba terhadap 30 responden awal, dari 20 item pertanyaa didapat koefisien korelasi sebesar 0,9593. Melalu pengujian alat ukur, disebarkan 100 kuesoner di sebuah SMU di Bandung didapatkan model regresi linear dari pengaruh sikap dan norma subjektif terhadap intensi. Kontribusi dari nilai Bi dari sikap dan norma subjektif terhadap intensi. Hasil pengujian model dilakukan sesuai dengan hipotesis yang dibuat, didapat Koefisien dan model regresi seperti tabel 2.

Berdasarkan hasil analisis pada tabel 2, maka model regresi linier berganda yang didapat adalah sebagai berikut:

\section{$Y=1,788+0,00991 X 1-0,000718 X 2+\varepsilon$}

Dari model regresi tersebut dapat dijelaskan bahwa $\alpha=$ konstanta sebesar 3,125 artinya apabila semua variabel independen (X1 dan X2) dianggap konstan (bernilai 0), maka nilai intensi sebesar 3,125.Besarnya Sikap (X1) sebesar 0,0099 artinya apabila Sikap (X1) mengalami kenaikan sebesar 1 
sedangkan variabel lainnya dianggap konstan maka intensi akan mengalami kenaikan sebesar 0,0099. Besarnya norma subjektif (X2) sebesar -0,000718, artinya apabila norma subjektif (X2) mengalami kenaikan sebesar 1 sedangkan variabel lainnya dianggap konstan maka norma subjektif akan mengalami penurunan sebesar 0,000718.

Angka $\mathrm{R}$ sebesar 0.223 yang menunjukan bahwa korelasi/hubungan antara variabel 2 variabel independen-nya adalah rendah (Guilford, 1956). Angka R square koefisien determinasi adalah 0,05 (berasal dari 0,223 x 0,223). Namun digunakan adjusted $R$ square untuk menghindari bias terhadap jumlah variabel independen yang dimasukkan ke dalam model. Dari pengolahan data,diperoleh nilai adjusted $R$ square sebesar 0,04. Hal ini berarti $4 \%$ variasi dari intensi bisa dijelaskan oleh variasi dari kedua variabel independen. Sedangkan sisanya $96 \%$ dijelaskan oleh sebab-sebab yang lain.

Standard Error of Estimate (SEE) adalah 0,8105 atau $81 \%$ kesalahan dari estimasi. Makin kecil SEE akan membuat model regresi semakin tepat dalam memprediksi variabel independen.

Nilai $\mathrm{F}$ adalah 2,534 dengan tingkat signifikansi 0,085 . Karena probabilitasnya lebih besar dar 0,05 maka model regresi tidak dapat digunakan untuk memprediksi Intesni, atau dapat dijelaskan bahwa sikap dan norma subejektif secara bersama-sama tidak mempengaruhi Intensi untuk mengkonsumsi rokok kalangan remaja.

$$
\text { Koefisien regresi 0,00991 }
$$

menunjukkan bahwa ada hubungan positif antara sikap dengan intensi, dimana bahwa setiap penambahan nilai sikap sebesar 1 maka akan menigkatkan nilai intensi sebesar 0,00991. Pengaruh sikap terhadap mengkonsumsi rokok menambah intensi untuk mengkonsumsi rokok, namun karena signifikansi dari sikap terhadap rokok tidak signifikansi, maka pengaruhi sikap di asumsikan dapat diabaikan dan intensi sebesar 3,125 menandakan bahwa intensi untuk mengkonsumsi rokok maka intensinya mendekati ragu-ragu.

$$
\text { Koefisien regresi }-0,000718
$$

menunjukkan bahwa ada hubungan negatif antara norma subjektif dengan intensi, dimana setiap penambahan nilai sikap sebesar 1 maka akan menurunkan nilai intensi sebesar -0,000718. Pengaruh subjektif justru mengurangi intensi mengkonsumsi rokok, namun karena pengaruh norma subjektif tidak signifikan, maka pegaruh norma subjektif diasumsikan dapat diabaikan dan nilai intensi untuk mengkonsumsi rokok sebesar 3.125 menandakan bahwa keinginan untuk mengkonsumsi rokok mendekati ragu-ragu.

\section{Pembahasan}

Dilihat dari signifikansi intensi dipengaruhi oleh sikap (kuat, gaya, gagah, gaul, fleksibel dan berani) siswa terhadap mengkonsumsi rokok. Intensi tidak dipengaruh oleh norma subjektif (teman, idola, keluarga) siswa terhadap mengkonsumsi rokok. Kemungkinan penyimpangan yang timbul adalah faktor sampling error dan non sampling error (Woodside et al. 1977). Tingkah laku manusia yang di khususkan (perilaku merokok) tidak dapat mengsahihkan sikapsikap (Amana, 2002) dan norma subjektif, dimana model behavior intention tidak dapat menjawab hipotesis yang diajukan.

\section{Keterbatasan}

Pada penelitian membahas perilaku khusus untuk siswa SMU belajar di lokasi penelitian. Hasil ini seharusnya sama bila digunakan di untuk mendukung penelitian sebelumnya. Hasil mungkin berbeda dengan bukan siswa SMU. Hasil yang berbeda disebabkan faktor psikologis dan demografis (Amana, 2002) sampel penelitian. Keterbatasan lain adalah besarnya sampel, biaya tinggi dan kesulitan dalam penerapannya (Mandel, 1974). Meskipun jumlah partisipan mencukupi, namun dapat ditingkatkan untuk meningkatkan keandalannya. 


\section{KESIMPULAN DAN SARAN Kesimpulan}

Adapun kesimpulan yang diapatkan adalah sebagai berkut : sikap (kuat, gaya, gagah, gaul, fleksibel dan berani) mempengaruhi siswa terhadap Intensi untuk mengkonsumsi rokok. Sedangkan norma subjektif (teman, idola, keluarga) tidak mempengaruh intensi siswa untuk mengkonsumsi rokok. Sikap dan norma subejektif secara bersama-sama tidak mempengaruhi intensi untuk mengkonsumsi rokok.

\section{Saran}

Penelitian ini dapat di lanjutkan menggunakan model Teori Perilaku Terencana / Theory of Planned Behavior (TPB) merupakan perluasan dari Theory of Reasoned Action (TRA), dimana dalam TPB ditambahkan satu faktor lagi yaitu perceived behavioral control (Ajzen, 1991) untuk melihat hubungan antara niat dengan sikap, norma subjektif dan control perilaku.

\section{DAFTAR PUSTAKA}

Ajzen, I. (1991). The Theory of Planned Behavior. Organizational Behavior and Human Decision Process, Vol. 50, 179211.

Amana, N.I. (2002). Analisis Profil Demografis Dan Psikografids Perokok Merek Marlboro. Tugas Akhir Sarjana Jurusan Teknik Industri, Institut Teknologi Bandung.

Cohen, J., \& Cohen. P. (1983). Applied Multiple Regression / Correlation Analysis for the behavioral Sciences, $\left(2^{\text {nd }} e d\right)$. London: Lawrence Erlbaum Associates Publisher.
Dajan, A. (1986). Pengantar Metode Statistik, Jilid II. Jakarta: LP3ES.

Fishbein. M., \& Ajzen. I. (1975). Belief, Attitude, Intention and Behavior : An Introduction to Theory and Research. Manila: Addisson-Wesley Company Inc.

Fishbein. M., \& Ajzen. I. (1980), Understanding Attitude and Predicting Social Behavior. London: Prentice-Hall International, Inc.

Hays, W.L. (1969). Quantification in Psychology : A life Span Approach. New Delhi: Prentice Hall of India Private Limited.

Utamadi, G. (2002). Rokok Bagi Remaja, Gaya atau Bahaya?. Jakarta: Kompas.

Koncara, A. (2009). Analisis Pengaruh Sikap dan Norma Subjektif Terhadap Intensi serta Perilaku Mengkonsumsi Produk $X$ di Kalangan Remaja Berdasarkan TRA.Tesis Magister, Instutut Teknologi Bandung.

Kotler, P. (1980). Principles of Marketing. New Jersey: Prentice-Hall.

Mandel, M. J. (1974). The Background of Advertising and It's Social Impaction. New Jersey: Prentice-Hall.

Nurhayati, A. (2001). Pengukuran Minat Konsumen Untuk Membeili Berdasarkan Model Ajzen dan Fishbein (studi kasus : Produk Minyak Goreng). Tugas Akhir Sarjana jurusan Teknik Industri. Institut Teknologi Bandung.

Peslak, A., Ceccucci, W., \& Sendall, P. (2011). An Empirical Study of Socialing Networking Behaviour Using Theory of Reasoned Action. CONISAR Proceedings Vol. 4 No. 1807. 